\title{
Posterior Median Fissure of the Spinal
} Cord

National Cancer Institute

\section{Source}

National Cancer Institute. Posterior Median Fissure of the Spinal Cord. NCI Thesaurus.

Code C33366.

A narrow groove in the center of the posterior surface of the spine. 